\title{
Acid Activation of Immediate Early Genes in Renal Epithelial Cells
}

Yasuyoshi Yamaji, Orson W. Moe, R. Tyler Miller, and Robert J. Alpern

Department of Internal Medicine, University of Texas Southwestern Medical Center, Dallas, Texas 75235

\begin{abstract}
These studies examined the effect of acidosis on immediate early (IE) gene expression in renal tubule cells. In MCT cells, an SV40 transformed mouse proximal tubule cell line, incubation in acid media led to transient increases in c-fos, c-jun, junB, and egr-1 mRNA abundance, peaking at $30 \mathrm{~min}$ to $1 \mathrm{~h}$. In vivo metabolic acidosis caused more prolonged increases in these mRNA species in renal cortex. Nuclear runon studies demonstrated increased rates of transcription for these IE genes. In addition, pretreatment of cells with cycloheximide caused superinduction of these mRNA by acid incubation. These responses are similar to those elicited by growth factors. Inhibition of tyrosine kinase pathways prevented IE gene activation by acid, while inhibition of protein kinase $C$ and/or increases in cell calcium had no effect. In $3 T 3$ cells, acid activated IE genes by a different mechanism in that the increase in mRNA did not include cjun, was more prolonged, and was blocked by cycloheximide. In summary, incubation of renal cells in acid media leads to activation of IE genes that is similar to growth factor-induced IE gene activation, and is likely mediated by tyrosine kinase pathways. (J. Clin. Invest. 1994. 94:12971303.) Key words: fos • jun • egr • tyrosine kinase • herbimycin A
\end{abstract}

\section{Introduction}

Chronic metabolic acidosis causes an increase in renal net acid excretion. In the renal proximal tubule this is associated with growth, an increased capacity for $\mathbf{H}$ secretion, and increased ammonia synthesis. The $\mathrm{Vmax}$ of the apical membrane $\mathrm{Na} / \mathrm{H}$ antiporter and the basolateral membrane $\mathrm{Na} / \mathrm{HCO}_{3} / \mathrm{CO}_{3}$ cotransporter, and activities of three ammoniagenic enzymes, phosphate-dependent glutaminase, glutamate dehydrogenase, and phosphoenolpyruvate carboxykinase, are all increased (15 ). Acid incubation of cultured renal cells (primary cultures, MCT, OKP, LLC-PK1) causes an increase in $\mathrm{Na} / \mathrm{H}$ antiporter activity at $24-48 \mathrm{~h}$ that is dependent on protein synthesis, and is associated with an increase in $\mathrm{Na} / \mathrm{H}$ antiporter mRNA (NHE1 isoform; MCT, LLC-PK1) (6-8). This effect was found to be cell specific, in that acid incubation decreased $\mathrm{Na} / \mathrm{H}$ antiporter activity and NHE-1 mRNA abundance at $24 \mathrm{~h}$ in primary cul-

Address correspondence to Robert J. Alpern, MD, Division of Nephrology, UT Southwestern, 5323 Henry Hines Blvd., Dallas, TX 752358856.

Received for publication 20 August 1993 and in revised form 22 February 1994.

J. Clin. Invest.

(c) The American Society for Clinical Investigation, Inc.

0021-9738/94/09/1297/07 \$2.00

Volume 94, September 1994, 1297-1303 tures of human foreskin fibroblasts and NIH 3T3 cells $(6,7)$. Acid incubation of LLC-PK1-F+ cells increases the abundance of mRNA for the above three ammoniagenic enzymes within $24 \mathrm{~h}(4,9)$. The molecular mechanisms responsible for the above adaptations have not been defined.

Growth related immediate early (IE) ${ }^{1}$ genes may play a role. Acid incubation increases the abundance of c-fos (15-30 min) and c-jun ( $1 \mathrm{~h}$ ) mRNA in MCT cells (10). In addition, in MCT cells stably transfected with an AP-1/CAT reporter gene construct, acid incubation caused a 3-fold increase in chloramphenicol acetyltransferase (CAT) activity and CAT mRNA at $3 \mathrm{~h}$, indicating increases in AP-1 (composed of heterodimers from the fos and jun gene families) activity (10). The present studies further address the effects of acid incubation on other members of the jun family and egr-1, the cell specificity of these effects, and the mechanisms responsible.

\section{Methods}

Cell culture. MCT cells were passaged in RPMI with $100 \mathrm{U} / \mathrm{ml}$ penicillin, $100 \mu \mathrm{g} / \mathrm{ml}$ streptomycin (pen/strep), and $10 \%$ fetal bovine serum. For experimentation, MCT cells were grown to $80 \%$ confluence on $10-$ $\mathrm{cm}$ plates and then medium was changed to DME/Ham's F12 (1:1) with pen/strep and without serum for $48 \mathrm{~h}$ prior to study. NIH 3T3 cells were passaged in DME with pen/strep and $10 \%$ calf serum. Cells were grown to confluence and then incubated in DME/Ham's F12 (1:1) with $0.5 \%$ calf serum and pen/strep for $48 \mathrm{~h}$ before experimentation.

To acidify media by $0.3 \mathrm{pH}$ units, 100 or $110 \mu \mathrm{l}$ of $1 \mathrm{~N} \mathrm{HCl}$ were added to $10 \mathrm{ml}$ of MCT or 3T3 media, respectively $(6,7)$. This amount of $\mathrm{HCl}$ induced the same range of acidification in both media $(0.5 \%$ calf serum increases the non-bicarbonate buffer capacity of the 3T3 media). For controls, similar volumes of deionized water were added. To measure the rate of protein synthesis, cells were incubated in $\left[{ }^{3} \mathrm{H}\right]-$ leucine for $3 \mathrm{~h}$ before and then during $3 \mathrm{~h}$ of incubation in control or acid media, and incorporation of counts into the TCA precipitable fraction was measured. To measure cell $\mathrm{Ca}$, cells were grown on glass coverslips, incubated with $20 \mu \mathrm{M}$ acetoxymethyl ester of Fura- 2 for 30 min, and Fura-2 fluorescence was measured at 340 and $380 \mathrm{~nm}$ excitation with $510 \mathrm{~nm}$ emission, as previously described $(6,11)$. The Fura2 signal was calibrated intracellularly with $5 \mu \mathrm{M}$ ionomycin and cell $\mathrm{Ca}$ calculated from the excitation ratio as described $(11,12)$.

Animals. Male Sprague-Dawley rats were gavaged with $2 \mathrm{M} \mathrm{NH}_{4} \mathrm{Cl}$ $(1 \mathrm{ml} / 100 \mathrm{~g})$, as described (4). Control rats were gavaged with similar volumes of water. At indicated times, rats were anesthetized with inactin $(100 \mathrm{mg} / \mathrm{kg}$ ), the kidney removed, and renal cortex dissected. Blood was collected from the aorta for measurement of arterial blood gases.

RNA preparation and analysis. Total cellular RNA was extracted using a modification of the method of Chirgwin et al. $(7,13)$. Cultured cells were scraped in guanidium thiocyanate solution ( $4 \mathrm{M}$ guanidium thiocyanate, $0.5 \% \mathrm{~N}$-lauroylsarcosine, $0.1 \mathrm{M}$ 2-mercaptoethanol, and 25 $\mathrm{mM}$ sodium citrate [ $\mathrm{pH} 7.0]$ ), disrupted by gentle aspiration through a 22-gauge needle twice, centrifuged through a $5.7 \mathrm{M} \mathrm{CsCl}$ cushion at

1. Abbreviations used in this paper: AP-1, activator protein 1; CAT, chloramphenicol acetyltransferase; DEPC, diethyl pyrocarbonate; IE, immediate early; PKC, protein kinase C; TCA, trichloracetic acid. 
$52,000 \mathrm{rpm}$ for $2 \mathrm{~h}$ at $20^{\circ} \mathrm{C}$ (Beckman Optima TLX; TL55 rotor: Beckman Instruments, Fullerton, CA ), and further purified by ethanol precipitation. Renal cortex was homogenized in the same guanidium thiocyanate solution, centrifuged at $10,000 \mathrm{~g}$ for $10 \mathrm{~min}$, and the supernatant processed as above. Total RNA was size fractionated by agarose-formaldehyde gel electrophoresis and transferred to nylon filters (GenescreenPlus; New England Nuclear, Boston, MA) in 20× SSC. Prehybridization, hybridization, washing, and exposure to film were performed as described previously $(7,10)$. Radiolabeled cDNA probes were made by random primer using the following inserts: full length c-fos (14); full length c-jun (15); full length junB (16); full length junD (17); egr-1, nucleotides 1552-2253 (18); and full length GAPDH (19).

Nuclear runon. Nuclei were prepared as described with modification (20). Cells were washed with ice cold PBS, scraped in sucrose buffer A (0.3 M sucrose, $2 \mathrm{mM} \mathrm{MgCl}_{2}, 3 \mathrm{mM} \mathrm{CaCl}_{2}, 10 \mathrm{mM}$ Tris- $\mathrm{HCl}$ [pH 8.0], $2.75 \mathrm{mM}$ DTT, $1 \mathrm{U} / \mathrm{ml}$ RNasin), disrupted by gentle aspiration through a 25-gauge needle three times, diluted 1:2 in sucrose buffer $\mathrm{B}$ (2.0 M sucrose, $5 \mathrm{mM} \mathrm{MgCl}_{2}, 10 \mathrm{mM}$ Tris- $\mathrm{HCl}$ [pH 8.0], $2.75 \mathrm{mM}$ DTT, $1 \mathrm{U} / \mathrm{ml} \mathrm{RNasin),} \mathrm{laid} \mathrm{over} \mathrm{an} \mathrm{equal} \mathrm{volume} \mathrm{of} \mathrm{sucrose} \mathrm{buffer} \mathrm{B}$, and centrifuged at $13,000 \mathrm{rpm}$ for $45 \mathrm{~min}$ at $2^{\circ} \mathrm{C}$ (Beckman L8-70M; SW28 rotor: Beckman Instruments). The nuclear pellet was washed in buffer ( $150 \mathrm{mM} \mathrm{KCl}, 5 \mathrm{mM} \mathrm{MgCl}, 0.1 \mathrm{mM}$ EDTA, $10 \mathrm{mM}$ Tris- $\mathrm{HCl}$ [ $\mathrm{pH} 8.0]$ ), resuspended in glycerol storage buffer $(50 \mathrm{mM}$ Tris- $\mathrm{HCl}$ [pH 8.3], $40 \%$ glycerol, $5 \mathrm{mM} \mathrm{MgCl}_{2}, 0.1 \mathrm{mM}$ EDTA), and stored at $-70^{\circ} \mathrm{C}$

For nuclear runon, $5 \times 10^{6}$ nuclei were thawed at room temperature, diluted $1: 1$ in $2 \times$ reaction buffer $(430 \mathrm{mM} \mathrm{KCl}, 7 \mathrm{mM} \mathrm{MgCl}, 14 \mathrm{mM}$ Tris- $\mathrm{HCl}$ [pH 8.0], $1 \mathrm{mM}$ each of ATP, CTP, and GTP [RNase-free, Promega ], $5 \mathrm{mM}$ DTT, $\left.0.13 \mathrm{mM}[100 \mu \mathrm{Ci}] \alpha-\left[{ }^{32} \mathrm{P}\right] \mathrm{UTP}\right)$, and incubated for $30 \mathrm{~min}$ at $30^{\circ} \mathrm{C}$ with shaking. The reaction was terminated by centrifugation for 30 seconds at $10,000 \mathrm{~g}$; the supernatant was ethanol precipitated with carrier tRNA; and the nuclear pellet was dissolved in $0.7 \mathrm{ml}$ of guanidium thiocyanate solution and sheared sequentially through 20-gauge, 22-gauge, and 25-gauge needles. The supernatant and nuclear pellet fractions were combined and centrifuged through a $5.7 \mathrm{M} \mathrm{CsCl}$ cushion as above. The RNA pellet was dissolved in $80 \mu \mathrm{l}$ of DEPC water containing $1 \mathrm{U} / \mathrm{ml}$ RNasin and further purified with a BIO-SPIN-20 column (Bio-Rad Laboratories, Richmond, CA). The flow through was precipitated, the pellet suspended, incubated in $0.1 \mathrm{~N}$ $\mathrm{NaOH}$ on ice for $10 \mathrm{~min}$, and then neutralized. For hybridization, nylon membranes containing immobilized linearized plasmids were prehybridized (10 mM Hepes [pH 7.5], 0.5 M NaCl, $10 \mathrm{mM}$ EDTA, $0.2 \%$ SDS, $0.2 \%$ Ficoll, $0.02 \%$ polyvinylpyrrolidone for $2 \mathrm{~h}$ at $65^{\circ} \mathrm{C}$ ), and hybridized in the same solution containing $2 \times 10^{6} \mathrm{cpm}$ of RNA sample at $65^{\circ} \mathrm{C}$ for $36 \mathrm{~h}(21)$. The blot was then washed twice with $0.1 \%$ SDS, $2 \times \mathrm{SSC}$ for $5 \mathrm{~min}$ at room temperature, washed with $0.5 \%$ SDS, $0.1 \times$ $\mathrm{SSC}$ for $30 \mathrm{~min}$ at $50^{\circ} \mathrm{C}$, rinsed with $2 \times \mathrm{SSC}$, incubated with $10 \mu \mathrm{g} /$ $\mathrm{ml}$ RNase-A in $2 \times \mathrm{SSC}$ for $1 \mathrm{~h}$ without shaking, and then washed with $0.5 \% \mathrm{SDS}, 0.1 \% \mathrm{SSC}$ for $30 \mathrm{~min}$ at $50^{\circ} \mathrm{C}$. Signals on autoradiographs were quantitated by laser densitometer.

Chemicals. All chemicals were obtained from Sigma Chemical Co. (St. Louis, MO) unless otherwise noted as follows: penicillin and streptomycin from Whittaker M. A. Bioproducts (Walkersville, MD); culture media, herbimycin A, and geldanomycin from Gibco (Grand Island, NY); dimethyl BAPTA (1,2-bis[2-aminophenoxy ]ethane-n, $n, n^{1}, n^{1}$-tetracetic acid) from Molecular Probes, Inc. (Eugene, OR); PMA, genistein, and tyrphostin A47 from LC Services Corp. (Woburn, MA); and ${ }^{32} \mathrm{P}-\mathrm{dATP}$ and $\left[{ }^{32} \mathrm{P}\right] \mathrm{UTP}$ from New England Nuclear.

\section{Results}

Acid incubation increases immediate early gene mRNA abundance. We previously demonstrated that incubation of MCT cells, an SV40 transformed mouse proximal tubule cell line, in acid media increases mRNA abundance for c-fos and c-jun. Fig. $1 A$ shows the timecourse of the effect of acid incubation on mRNA for these and a number of other IE genes. Acid

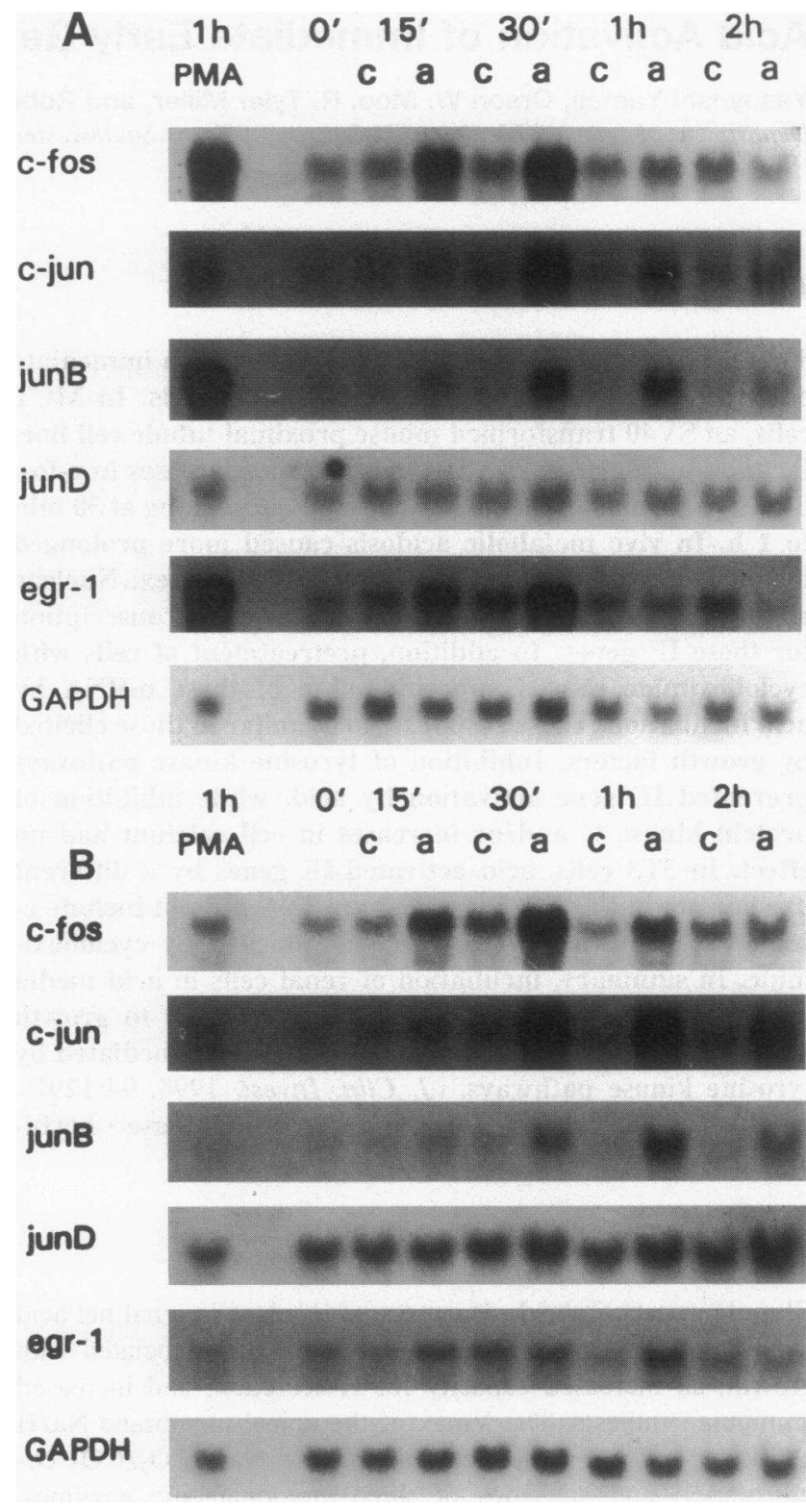

Figure 1. Effect of acid incubation or PMA on IE gene mRNA abundance in MCT cells. MCT cells were serum deprived for $48 \mathrm{~h}$ and then incubated in either control $(c)$, or acid $(a)$ media, or control media with $100 \mathrm{nM}$ PMA (PMA). Cells were harvested at the times indicated and mRNA abundance measured on total RNA. $(A)$ Cells were pretreated with DMSO for $24 \mathrm{~h}$ before experimentation. (B) Cells were pretreated with $400 \mathrm{nM}$ PMA in DMSO for $24 \mathrm{~h}$ before experimentation.

incubation caused five- to sixfold increases in c-fos, c-jun, and junB mRNA abundance. Acid incubation also increased egr-1 mRNA abundance, but this increase was only twofold. The increases in c-fos and egr- 1 mRNA peaked and decreased earlier than those of c-jun and junB mRNA, consistent with previous observations, and likely due to inhibition of the serum response element by Fos protein (22). There was a tendency for junD mRNA abundance to increase, but this was not significant, consistent with the previously found constitutive expression of junD (23). For comparison, 5\% serum addition to these cells caused a 36-fold increase in c-fos, a 10-fold increase in c-jun, a 13- 


\section{$0^{\prime} 15^{\prime} 30^{\prime} \quad 1 \mathrm{~h} \quad 2 \mathrm{~h} \quad 3 \mathrm{~h}$ c a c a c a c a c a}

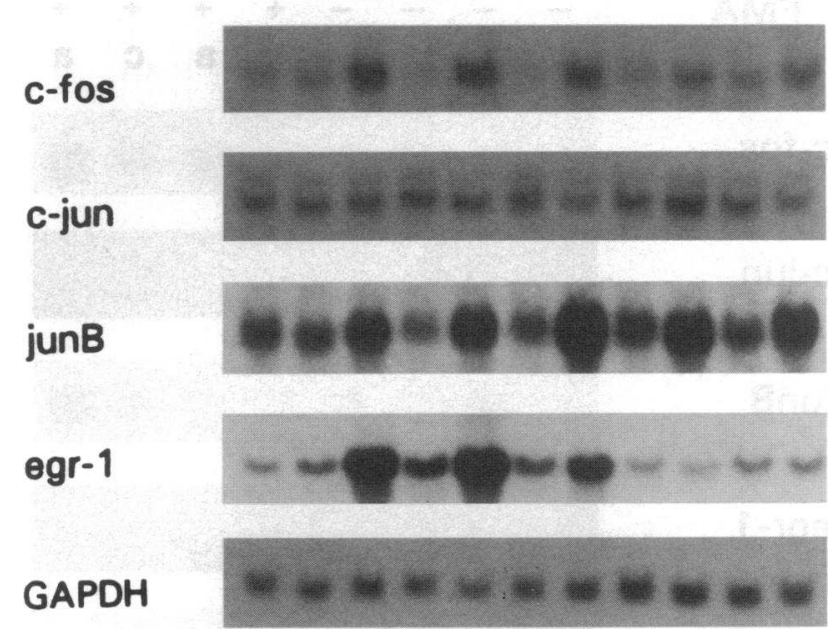

Figure 2. Effect of acid incubation on IE gene mRNA abundance in NIH 3T3 fibroblasts. Data are displayed as in Fig. 1. The blot shown for egr-1 was obtained from a separate group of cells than the other blots, because technical quality following multiple rounds of probing and stripping was not adequate.

fold increase in junB, and a 24-fold increase in egr-1 mRNA abundance (data not shown).

Acid activation of immediate early genes is tissue specific. While acidosis increases renal proximal tubular growth, it inhibits growth of most other cells $(24,25)$. In addition, we found that acid incubation increases $\mathrm{Na} / \mathrm{H}$ antiporter activity and NHE-1 mRNA in proximal tubule cells, but decreases them in fibroblasts $(6,7)$. To examine whether IE gene activation by acid was tissue specific, we examined the effect of acid incubation in NIH 3T3 cells. Fig. 2 shows that acid incubation caused a fivefold increase in c-fos mRNA abundance, similar to that observed in MCT cells. However, it should be noted that the increase in c-fos mRNA was more prolonged, and was still present after $2 \mathrm{~h}$. This timecourse is not typical for activation of c-fos by growth factors, but can be seen with protein synthesis inhibition (26). Acid incubation also caused prolonged increases in junB and egr-1 mRNA abundance, but had no effect on c-jun mRNA.

Because inhibition of protein synthesis can activate IE genes, we next examined whether this was the mechanism responsible for acid activation in MCT and 3T3 cells. First, we measured the effect of acid incubation on $\left[{ }^{3} \mathrm{H}\right]$ leucine incorporation in MCT and 3T3 cells. For these studies, we concentrated on early effects, corresponding with the timecourse of IE gene activation. $\left[{ }^{3} \mathrm{H}\right.$ ] Leucine was added $3 \mathrm{~h}$ before control or acid incubation, and cells were scraped $3 \mathrm{~h}$ after incubation. As can be seen in Table I, acid incubation inhibited protein synthesis in 3T3 cells, but had no effect in MCT cells.

Next, we examined the effect of acid incubation on IE gene expression in the presence of prior protein synthesis inhibition with cycloheximide. In the presence of cycloheximide, growth factors are known to superinduce IE gene mRNA (26-29). We reasoned that any mechanism that worked through inhibition of protein synthesis would be unlikely to have an additional effect in the presence of cycloheximide. Cells were pretreated with 7
Table I. Effect of $3 \mathrm{~h}$ of Acid Incubation on $\left[{ }^{3} \mathrm{H}\right]$ Leucine Incorporation*

\begin{tabular}{lcc}
\hline & MCT & 3T3 \\
\hline Control & $135317 \pm 62950$ & $7905 \pm 2739$ \\
Acid & $133185 \pm 60281$ & $5943 \pm 1928$ \\
& NS $^{\ddagger}$ & $P<0.01^{\ddagger}$ \\
\hline
\end{tabular}

* cpm, mean \pm SEM, ${ }^{\ddagger}$ paired $t$ test, $n=6$.

$\mu \mathrm{M}$ cycloheximide for $\mathbf{1 2 0} \mathrm{min}$ before control or acid incubation. This dose of cycloheximide was found to inhibit $\left[{ }^{3} \mathrm{H}\right]-$ leucine incorporation by $97 \%$ in MCT cells and $95 \%$ in NIH 3T3 cells. Cycloheximide treatment caused activation of IE genes in MCT and 3T3 cells (Fig. 3, $A$ and $B$ ). As can be seen in Fig. $3 A$, in MCT cells acid addition then superinduced cfos, c-jun, junB, and egr-1 mRNA, causing more prolonged increases in mRNA abundance. The ability of acid incubation to activate these genes in the presence of cycloheximide proves

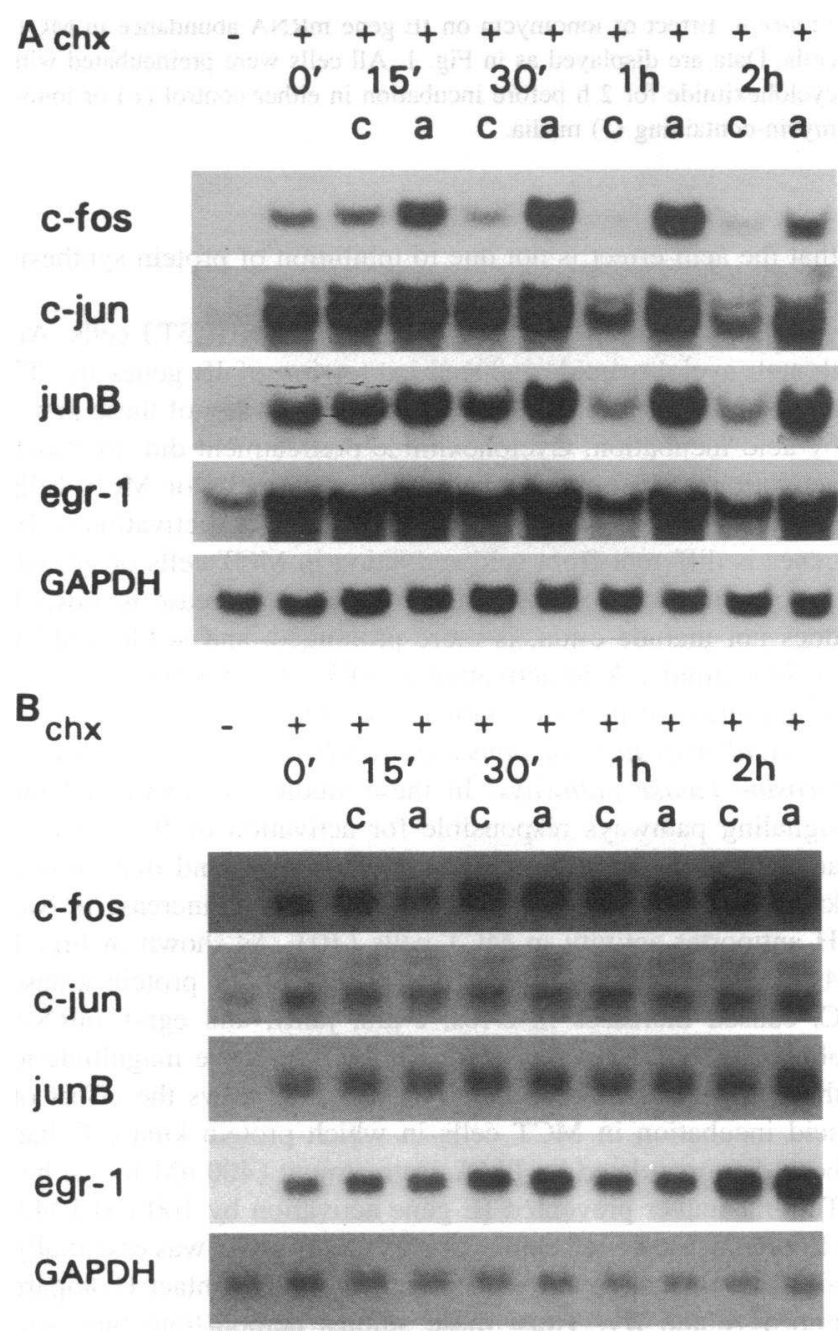

Figure 3. Effect of cycloheximide and acid incubation on IE gene mRNA abundance. Data are displayed as in Fig. 1. chx (+ or -) indicates pretreatment of cells with cycloheximide for $2 \mathrm{~h}$. (A) MCT cells. (B) NIH 3 T3 cells. 


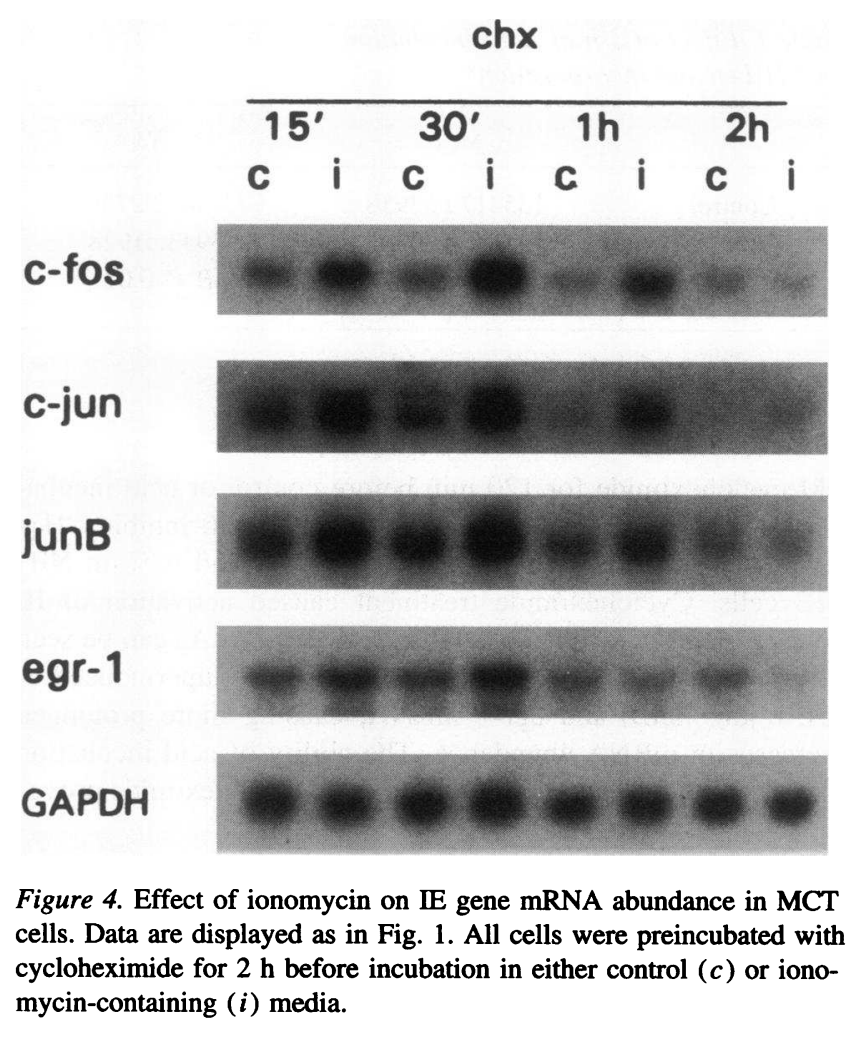

that the acid effect is not due to inhibition of protein synthesis in MCT cells.

Fig. $3 B$ shows similar experiments in NIH 3T3 cells. Although cycloheximide induced expression of IE genes in 3T3 cells, there was no additional stimulation of any of these genes by acid incubation. Cycloheximide pretreatment did not block activation of c-fos by PMA in NIH 3T3 cells or MCT cells (data not shown). Thus, in NIH 3T3 cells acid activation of IE genes is different from acid activation in MCT cells or growth factor activation in most cells in that: the increase in mRNA does not include c-jun, is more prolonged, and is blocked by cycloheximide. Acid activation in 3T3 cells may be secondary to inhibition of protein synthesis (see Discussion).

Acid activation of immediate early genes is mediated by tyrosine kinase pathways. In these studies we examined the signaling pathways responsible for activation of IE genes by acid in MCT cells. In previous studies we found that protein kinase $\mathrm{C}$ played a key role in the acid-induced increase in $\mathrm{Na}$ / $H$ antiporter activity in MCT cells (10). As shown in Fig. 1 $A, 100 \mathrm{nM}$ PMA, a phorbol ester activator of protein kinase $C$, caused increases in c-fos, c-jun, junB, and egr-1 mRNA abundance after $1 \mathrm{~h}$ that were similar in relative magnitude to those seen with acid incubation. Fig. $1 B$ shows the effect of acid incubation in MCT cells in which protein kinase $C$ had been downregulated by PMA pretreatment ( $400 \mathrm{nM}$ for $24 \mathrm{~h}$ ). This maneuver prevented IE gene activation by $100 \mathrm{nM}$ PMA (Fig. $1 B$ ). However, acid activation of IE genes was essentially identical to that found with protein kinase $\mathrm{C}$ intact (compare Fig. $1 A$ and $B$ ). Thus, these studies demonstrate that acid incubation is able to activate IE genes in the absence of PMAactivatable protein kinase $\mathrm{C}$.

To study the effect of increases in cell calcium, $10^{-7} \mathrm{M}$ ionomycin was added to cells. To eliminate possible effects of

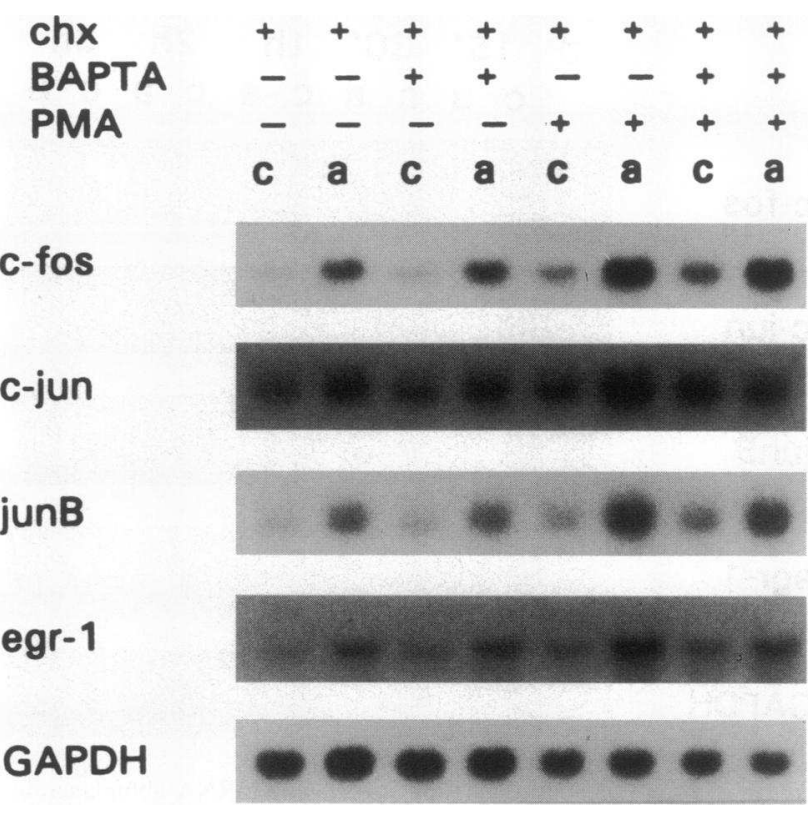

Figure 5. Effect of acid incubation on IE gene mRNA abundance in MCT cells: inhibition by BAPTA and/or PMA pretreatment. Data are presented as in Fig. 1. All cells were pretreated with cycloheximide for $2 \mathrm{~h}$ before experimentation. As indicated, cells were also treated before experimentation with either dimethyl BAPTA for $1 \mathrm{~h}$ and/or PMA for $24 \mathrm{~h}$ before experimentation. Cells were incubated in control or acid media for $1 \mathrm{~h}$.

ionomycin on protein synthesis as a variable, cells were pretreated with $7 \mu \mathrm{M}$ cycloheximide for $2 \mathrm{~h}$ before and during ionomycin or vehicle addition. As shown in Fig. 4, ionomycin caused an increase in IE gene mRNA abundance. The increase in c-fos mRNA was more pronounced (fivefold) than the increase in c-jun, junB, and egr-1 mRNA (approximately twofold).

To examine the role of increased cell $\mathrm{Ca}$ in acid activation, two sets of studies were performed. First, we measured cell Ca with Fura-2. Acidification of extracellular fluid did not increase, but decreased cell Ca from $111 \pm 58 \mathrm{nM}$ to $85 \pm 42 \mathrm{nM}(n=5$, $P<0.005$ ). As a control, we examined the effect of bradykinin. $10 \mathrm{nM}$ bradykinin caused a spike increase in cell $\mathrm{Ca}$ from $133 \pm 47 \mathrm{nM}$ to $310 \pm 157 \mathrm{nM}(n=5, P<0.02)$. Second, we examined the effect of pretreatment with $20 \mu \mathrm{M}$ acetoxymethyl ester of dimethyl BAPTA for $30 \mathrm{~min}$ on acid-induced IE gene activation. This maneuver lowers cell $\mathrm{Ca}$ and clamps cell $\mathrm{Ca}$ low (11), and inhibited the above bradykinin-induced increase in cell $\mathrm{Ca}$. Once again, for these studies, cells were pretreated with cycloheximide to eliminate possible effects on protein synthesis as a variable. Fig. 5 shows results of $1 \mathrm{~h}$ acid incubation following $30 \mathrm{~min}$ BAPTA and/or $24 \mathrm{~h}$ PMA pretreatment. Neither of these maneuvers prevented acid activation of the IE genes.

IE gene activation typically is mediated by activation of protein kinase $\mathrm{C} / \mathrm{Ca}$ signaling pathways and/or tyrosine kinase pathways. To examine whether tyrosine kinase pathways mediate the acid effect, we examined the effect of herbimycin $A$ on acid-induced increases in IE gene mRNA. Herbimycin $A$ is a potent, specific inhibitor of tyrosine kinase pathways (30). Once again, studies were performed $2 \mathrm{~h}$ after cycloheximide 


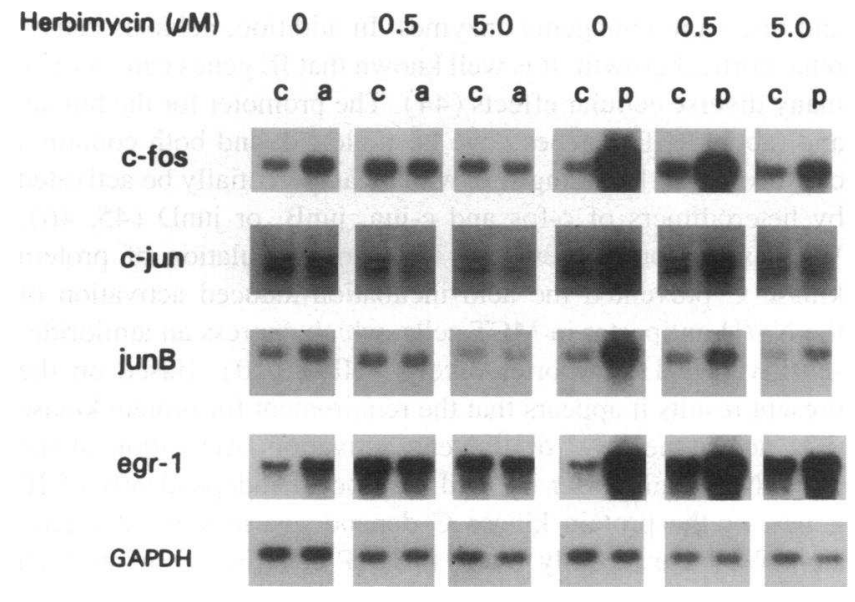

Figure 6. Effect of acid incubation or PMA on IE gene mRNA abundance in MCT cells: inhibition by herbimycin A. Data are presented as in Fig. 1. All cells were treated with cycloheximide for $2 \mathrm{~h}$ before experimentation. Cells were treated with herbimycin A or vehicle (DMSO), as indicated for $24 \mathrm{~h}$. Cells were then treated with acid ( $a$ ) or $100 \mathrm{nM}$ PMA $(p)$ for $1 \mathrm{~h}$.

addition, to eliminate nonspecific effects on protein synthesis. Cells were pretreated with herbimycin A or vehicle for $24 \mathrm{~h}$ before study (30-32). As shown in Fig. 6, 0.5 and $5 \mu \mathrm{M}$ herbimycin A completely inhibited activation of IE genes by incubation in acid media for $1 \mathrm{~h}$. As a control, the effect of herbimycin A on IE gene activation by $100 \mathrm{nM}$ PMA for $1 \mathrm{~h}$ was studied. Herbimycin A only partially inhibited this effect. The partial inhibition of the PMA effect is consistent with activation of tyrosine kinase pathways by protein kinase C (33).

A number of other tyrosine kinase inhibitors were tested. After addition of cycloheximide for $2 \mathrm{~h}$, cells were treated with acid for $1 \mathrm{~h}$. Geldanomycin (34), $1 \mu \mathrm{M}$ applied for $16 \mathrm{~h}$, completely inhibited acid-induced IE gene mRNA increases (acid/control: c-fos, 0.9; c-jun, 1.0; junB, 1.0; egr-1, 1.0). Tyrphostin (35), $100 \mu \mathrm{M}$ applied for $16 \mathrm{~h}$, also completely blocked increases (acid/control: c-fos, 1.1; c-jun, 1.0; junB, 1.1; egr-1, 1.0). Genistein (36), $250 \mu \mathrm{M}$ applied for $30 \mathrm{~min}$, however, did not inhibit this process (acid/control: c-fos, 4.7; c-jun, 2.8; junB, 1.8; egr-1, 8.5). Orthovanadate, a tyrosine phosphatase inhibitor applied for $15 \mathrm{~min}$ at $200 \mu \mathrm{M}$, caused a marked increase in IE gene mRNA abundance, and partially inhibited acid activation (acid/control: c-fos, 1.6; c-jun, 1.5; junB, 1.5; egr-1, 1.1). These results suggest that acid activation of IE gene expression is mediated by tyrosine kinases and phosphatases.

Acid activation of immediate early genes is transcriptional. To examine whether the acid incubation-induced increase in IE gene mRNA abundance is transcriptional, nuclear runon studies were performed. Cells were incubated in control or acid media for $30 \mathrm{~min}$, nuclei isolated, and nuclear runon was performed. Fig. 7 shows that transcription rates for c-fos, c-jun, junB, and egr-1 were significantly increased by acid. There was also a small increase in junD transcription rate. As a control, there was no effect on GAPDH transcription rate.

Metabolic acidosis causes increases in renal cortical IE gene $m R N A$ in vivo. To examine whether the effects of acid incubation in MCT cells were relevant to effects of metabolic acidosis in vivo, rats were made acutely acidotic by gavage with $\mathrm{NH}_{4} \mathrm{Cl}$ as described (4). This maneuver caused blood

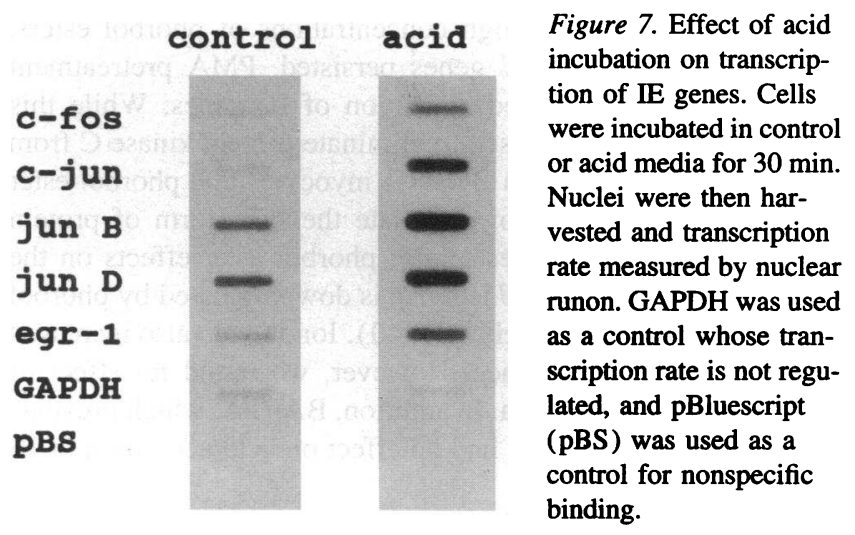

$\left[\mathrm{HCO}_{3}\right]$ to decrease to $16.3 \pm 1.4 \mathrm{meq} /$ liter at $1 \mathrm{~h}$, and then to gradually recover over $12 \mathrm{~h}$. As shown in Fig. 8, metabolic acidosis caused increases in renal cortical c-fos (2-4-fold), cjun (2-fold), junB (1.5-2-fold), and egr-1 (2-fold) mRNA abundance. These results are similar to those obtained with in vitro acid incubation, except that mRNA increases were more prolonged in vivo.

\section{Discussion}

These studies demonstrate that acid incubation of MCT cells, a renal proximal tubule cell line, leads to increases in c-fos, cjun, junB, and egr-1 mRNA abundance. This effect of acid is similar to that of growth factors on IE genes in a number of respects. First, activation is transient, with c-fos and egr-1 mRNA peaking and declining earlier than $\mathrm{c}$-jun or junB. We were somewhat surprised to observe a greater increase in c-fos $(5 \times)$ than egr-1 $(2 \times)$ mRNA abundance, as growth factors typically activate egr-1 more than c-fos (37). However, we also observed a greater increase in c-fos than egr-1 mRNA abundance with PMA, suggesting that this may be a property of these cells. Second, inhibition of protein synthesis with cycloheximide does not prevent IE gene activation by acid, and in fact causes superinduction. Third, acid activation is, at least in part, transcriptional. Fourth, acid activation is mediated by tyrosine kinase pathways. The similarity between growth factor and acid activation of IE genes could be due to acid-induced secretion of an autocoid growth factor.

PMA increased IE gene mRNA abundance in MCT cells. However, when protein kinase $\mathrm{C}$ was downregulated by pre-

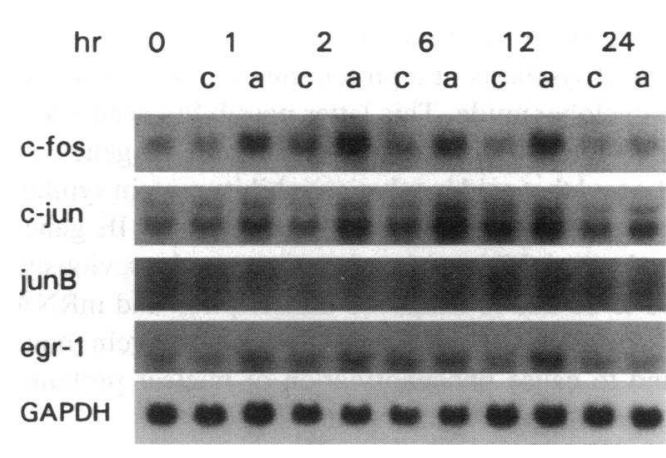

Figure 8. Effect of metabolic acidosis on renal cortical IE gene mRNA abundance. Data are presented as in Fig. 1. 
treatment of cells with high concentrations of phorbol esters, acid activation of the IE genes persisted. PMA pretreatment did prevent PMA-induced activation of IE genes. While this maneuver is frequently used to eliminate protein kinase $C$ from cells, it has been noted in $\mathrm{BC} 3 \mathrm{H}-1$ myocytes that phorbol ester pretreatment does not downregulate the $\beta$ isoform of protein kinase $C$, although it does inhibit phorbol ester effects on the cell (38). However, the $\beta$ isoform is downregulated by phorbol ester treatment in other cells $(39,40)$. Ionomycin also increased IE gene mRNA abundance. However, we found no effect of acid incubation on cell $\mathrm{Ca}$. In addition, BAPTA, which prevents increases in cell calcium, had no effect on acid activation of IE genes.

Our results suggest that IE gene expression in response to acid is signaled via tyrosine kinase pathways. Tyrosine kinase pathways mediate increases in IE gene expression in response to many growth factors (41). Herbimycin A in low concentrations is a specific inhibitor of tyrosine kinase pathways (30). We found that herbimycin A completely inhibited acid induction of IE gene expression at $0.5 \mu \mathrm{M}$. By contrast, phorbol ester-induced increases in IE gene mRNA were inhibited only partially. This partial inhibition may be due to the fact that protein kinase $\mathbf{C}$ can activate tyrosine kinase pathways and mediate part of IE gene activation through these pathways (33). Similar results were found with two other tyrosine kinase inhibitors, geldanomycin and tyrphostin $(34,35)$. Genistein, another tyrosine kinase inhibitor (36), did not inhibit acid activation of IE genes. Growth hormone-induced tyrosine phosphorylation of certain proteins is inhibited by herbimycin A and tryphostin, but not by genistein (42). In support of a role for tyrosine kinase pathways, we recently found that acid incubation of MCT cells leads to increased phosphotyrosine content of 120- and 60-kD proteins (43). In addition, cell extracts from acid-treated MCT cells possess increased tyrosine kinase activity for a substrate that is specific for the src family of nonreceptor tyrosine kinases (43). A role for c-src (or src family members) in this pathway may explain the inhibition by orthovanadate in that csrc is activated by dephosphorylation of tyrosine 527 (or the equivalent tyrosine in other src family members).

In NIH 3T3 cells acid incubation increased IE gene mRNA abundance, but by an apparently distinct mechanism. In NIH 3 T3 cells, acid increased c-fos, junB, and egr- 1 mRNA abundance with no change in c-jun. In addition, IE gene mRNA increases were prolonged. Lastly, in 3T3 cells the acid-induced increases in IE gene mRNA were inhibited by cycloheximide pretreatment. This latter result has two possible explanations. First, if acid incubation increased IE gene mRNA abundance through protein synthesis inhibition, its effect would be prevented by prior protein synthesis inhibition. Second, if gene activation required synthesis of a protein intermediate, it would be blocked by cycloheximide. This latter possibility seems less likely given the rapid timecourse of activation of IE genes. In addition, we showed that acid incubation inhibits protein synthesis in 3T3 cells, but not in MCT cells. Induction of IE genes by protein synthesis inhibitors has been reported previously, and is believed to be due to enhanced transcription and mRNA stabilization (26-29). Cycloheximide and anisomycin have also been found to cause phosphorylation of nuclear proteins, possibly related to IE gene activation $(28,29)$.

The role of acid-induced IE gene activation in the proximal tubule remains to be determined. Acidosis causes increased activities of the $\mathrm{Na} / \mathrm{H}$ antiporter, the $\mathrm{Na} / \mathrm{HCO}_{3} / \mathrm{CO}_{3}$ symporter, and three ammoniagenic enzymes. In addition, acidosis causes renal cortical growth. It is well known that IE genes can mediate many diverse cellular effects (44). The promoter for the human and rabbit NHE-1 genes have been cloned, and both contain a conserved AP-1 binding site, which can potentially be activated by heterodimers of $c$-fos and c-jun, junB, or junD $(45,46)$. We have reported previously that downregulation of protein kinase $\mathrm{C}$ prevented the acid incubation-induced activation of the $\mathrm{Na} / \mathrm{H}$ antiporter in MCT cells, which express an amiloridesensitive $\mathrm{Na} / \mathrm{H}$ antiporter, likely NHE-1 (10). Based on the present results it appears that the requirement for protein kinase $\mathrm{C}$ is not at the level of IE gene activation. Activation of the MCT Na/H antiporter by acid may occur independently of IE genes, or the protein kinase $\mathrm{C}$ dependence may be at a later step. We have recently found in OKP cells, which express an amiloride-resistant $\mathrm{Na} / \mathrm{H}$ antiporter similar to that of the proximal tubule apical membrane, that acid activation of the $\mathrm{Na} / \mathrm{H}$ antiporter is inhibited by herbimycin A (unpublished observation, Y. Yamaji, M. Amemiya, O. W. Moe, and R. J. Alpern). Thus, tyrosine kinase pathways and IE genes may play a role in acid activation of the proximal tubule apical membrane $\mathrm{Na}$ / $\mathbf{H}$ antiporter.

In summary, exposure of cultured kidney cells to acid media leads to increases in mRNA abundance for c-fos, c-jun, junB, and egr-1. At least a component of this activation is transcriptional. The response of these IE genes to acidosis is similar in many respects to the response to growth factors, and is most likely mediated by tyrosine kinase pathways. In addition, the response is cell specific. It is likely that IE genes contribute in some manner to the renal response to acidosis, which involves increased activities and mRNA abundance of $\mathrm{H}$ transporters and ammoniagenic enzymes, and growth.

\section{Acknowledgments}

We gratefully acknowledge the technical expertise of Ladonna Crowder and Martha Ferguson. We also acknowledge helpful discussions with David Russell and the careful reading of the manuscript by Patricia Preisig, Michel Baum, and Chris Lu. cDNAs were provided generously by T. Curran (c-fos), V. Sukhatme (egr-1), and D. Nathans (c-jun, ATCC/NIH 63026; junB, ATCC/NIH 63025; junD, ATCC/NIH 63024). MCT cells were generously provided by E. Neilson.

This work was supported by grants DK-39298 and DK-41726 from the National Institutes of Health, and grants from the National Kidney Foundation of Texas. Y. Yamaji was supported by a grant from the National Kidney Foundation. O. Moe was supported by a grant from the American Heart Association, Texas Affiliate.

\section{References}

1. Akiba, T., V. K. Rocco, and D. G. Warnock. 1987. Parallel adaptation of the rabbit renal cortical sodium/proton antiporter and sodium/bicarbonate cotransporter in metabolic acidosis and alkalosis. J. Clin. Invest. 80:308-315.

2. Preisig, P. A., and R. J. Alpern. 1988. Chronic metabolic acidosis causes an adaptation in the apical membrane $\mathrm{Na} / \mathrm{H}$ antiporter and basolateral membrane $\mathrm{Na}\left(\mathrm{HCO}_{3}\right)_{3}$ symporter in the rat proximal convoluted tubule. J. Clin. Invest. 82:1445-14.53.

3. Hwang, J.-J., and N. P. Curthoys. 1991. Effect of acute alterations in acidbase balance on rat renal glutaminase and phosphoenolpyruvate carboxykinase gene expression. J. Biol. Chem. 266:9392-9396.

4. Kaiser, S., J.-J. Hwang, H. Smith, C. Banner, T. C. Welbourne, and N. P. Curthoys. 1992. Effect of altered acid-base balance and of various agonists on levels of renal glutamate dehydrogenase mRNA. Am. J. Physiol. 262:F507-F512.

5. Wright, P. A., R. K. Packer, A. Garcia-Perez, and M. A. Knepper. 1992. Time course of renal glutamate dehydrogenase induction during $\mathrm{NH}_{4} \mathrm{Cl}$ loading in rats. Am. J. Physiol. 262:F999-F1006. 
6. Horie, S., O. Moe, A. Tejedor, and R. J. Alpern. 1990. Preincubation in acid medium increases $\mathrm{Na} / \mathrm{H}$ antiporter activity in cultured renal proximal tubule cells. Proc. Natl. Acad. Sci. USA. 87:4742-4745.

7. Moe, O. W., R. T. Miller, S. Horie, A. Cano, P. A. Preisig, and R. J. Alpern. 1991. Differential regulation of $\mathrm{Na} / \mathrm{H}$ antiporter by acid in renal epithelial cells and fibroblasts. J. Clin. Invest. 88:1703-1708.

8. Igarashi, P., M. I. Freed, M. B. Ganz, and R. F. Reilly. 1992. Effects of chronic metabolic acidosis on $\mathrm{Na}^{+}-\mathrm{H}^{+}$exchangers in LLC-PK 1 renal epithelial cells. Am. J. Physiol. 263:F83-F88.

9. Kaiser, S., and N. P. Curthoys. 1991. Effect of pH and bicarbonate on phosphoenolpyruvate carboxykinase and glutaminase mRNA levels in cultured renal epithelial cells. J. Biol. Chem. 266:9397-9402.

10. Horie, S., O. Moe, Y. Yamaji, A. Cano, R. T. Miller, and R. J. Alpern. 1992. Role of protein kinase $C$ and transcription factor AP-1 in the acid-induced increase in $\mathrm{Na} / \mathrm{H}$ antiporter activity. Proc. Natl. Acad. Sci. USA. 89:5236-5240.

11. Hays, S. R., and R. J. Alpern. 1991. Inhibition of $\mathrm{Na}^{+}$-independent $\mathrm{H}^{+}$ Pump by $\mathrm{Na}^{+}$-induced changes in cell $\mathrm{Ca}^{2+}$. J. Gen. Physiol. 98:791-813.

12. Grynkiewica, G., M. Poenie, and R. Y. Tsien. 1985. A new generation of $\mathrm{Ca}^{2+}$ indicators with greatly improved fluorescence properties. J. Biol. Chem. 260:3440-3450.

13. Chirgwin, J. J., A. E. Przybyla, R. J. MacDonald, and W. J. Rutter 1979. Isolation of biologically active ribonucleic acid from sources enriched in ribonuclease. Biochemistry. 18:5294-5299.

14. Curran, T., M. G. Gordon, K. L. Rubino, and L. C. Sambucetti. 1987. Isolation and characterization of the c-fos (rat) cDNA and analysis of posttranslational modification in vitro. Oncogene. 2:79-84.

15. Ryder, K., and D. Nathans. 1988. Induction of protooncogene c-jun by serum growth factors. Proc. Natl. Acad. Sci. USA. 85:8464-8467.

16. Ryder, K., L. F. Lau, and D. Nathans. 1988. A gene activated by growth factors is related to the oncogene v-jun. Proc. Natl. Acad. Sci. USA. 85:14871491.

17. Ryder, K., A. Lanahan, E. Perez-Albuerne, and D. Nathans. 1989. Jun-D: A third member of the Jun gene family. Proc. Natl. Acad. Sci. USA. 86:15001503.

18. Sukhatme, V. P., X. Cao, L. C. Chang, C.-H. Tsai-Morris, D. Stamenkovich, P. C. P. Ferreira, D. R. Cohen, S. A. Edwards, T. B. Shows, T. Curran, M. M. Le Beau, and E. D. Adamson. 1988. A zinc finger-encoding gene coregulated with c-fos during growth and differentiation, and after cellular depolarization Cell. 53:37-43.

19. Fort, P., L. Marty, M. Piechaczyk, S. El Subrouty, C. Dani, P. Jeanteur, and J. M. Blanchard. 1985. Various rat adult tissues express only one majo mRNA species from the glyceraldehyde-3-phosphate-dehydrogenase multigenic family. Nucleic Acids Res. 13:1431-1442.

20. Messina, J. L. 1989. Insulin and dexamethasone regulation of a rat hepatoma messenger ribonucleic acid: insulin has a transcriptional and a posttranscriptional effect. Endocrinology. 124:754-761.

21. Noguchi, T., H. Inoue, and T. Tanaka. 1985. Transcriptional and posttranscriptional regulation of L-type pyruvate kinase in diabetic rat liver by insulin and dietary fructors. J. Biol. Chem. 260:14393-14397.

22. Lucibello, F. C., C. Lowag, M. Neuberg, and R. Muller. 1989. Transrepression of the mouse $\mathrm{c}$-fos promoter: a novel mechanism of fos-mediated transregulation. Cell. 59:999-1007.

23. de Groot, R. P., M. Karperien, C. Pals, and W. Kruijer. 1991. Characterization of the mouse junD promoter-high basal level activity due to an octamer motif. EMBO (Eur. Mol. Biol. Organ.) J. 10:2523-2532.

24. Lotspeich, W. D. 1965. Renal hypertrophy in metabolic acidosis and its relation to ammonia excretion. Am. J. Physiol. 208:1135-1142.

25. Pouyssegur, J., C. Sardet, A. Franchi, G. L'Allemain, and S. Paris. 1984. A specific mutation abolishing $\mathrm{Na} / \mathrm{H}$ antiport activity in hamster fibroblasts precludes growth at neutral and acidic pH. Proc. Natl. Acad. Sci. USA. 81:48334837.

26. Lau, L. F., and D. Nathans. 1987. Expression of a set of growth-related immediate early genes in BALB/c 3T3 cells: Coordinate regulation with c-fos or c-myc. Proc. Natl. Acad. Sci. USA. 84:1182-1186.

27. Greenberg, M. E., A. L. Hermanowski, and E. B. Ziff. 1986. Effect of protein synthesis inhibitors on growth factor activation of c-fos, c-myc, and actin gene transcription. Mol. Cell. Biol. 6:1050-1057.

28. Mahadevan, L. C., and D. R. Edwards. 1991. Signalling and superinduction. Nature (Lond.). 349:747-748.

29. Edwards, D. R., and L. C. Mahadevan. 1992. Protein synthesis inhibitors differentially superinduce c-fos and c-jun by three distinct mechanisms: lack of evidence for labile repressors. EMBO (Eur. Mol. Biol. Organ.) J. 11:2415-2424.

30. Uehara, Y., and H. Fukazawa. 1991. Use and selectivity of herbimycin A as inhibitor of protein-tyrosine kinases. Methods Enzymol. 201:370-379.

31. Uckun, F. M., G. L. Schieven, L. M. Tuel-Ahlgren, I. Dibirdik, D. E. Myers, J. A. Ledbetter, and C. W. Song. 1993. Tyrosine phosphorylation is a mandatory proximal step in radiation-induced activation of the protein kinase $\mathrm{C}$ signaling pathway in human B-lymphocyte precursors. Proc. Natl. Acad. Sci. USA. 90:252-256.

32. Uckun, F. M., G. L. Schieven, I. Dibirdik, M. Chandan-Langlie, L. TuelAhlgren, and J. A. Ledbetter. 1991. Stimulation of protein tyrosine phosphorylation, phosphoinositide turnover, and multiple previously unidentified serine-threonine-specific protein kinases by the pan-B-cell receptor CD40/Bp50 at discrete developmental stages of human B-cell ontogeny. J. Biol. Chem. 266:1747817485.

33. Force, T., J. M. Kyriakis, J. Avruch, and J. V. Bonventre. 1991. Endothelin, vasopressin, and angiotensin II enhance tyrosine phosphorylation by protein kinase $\mathrm{C}$-dependent and -independent pathways in glomerular mesangial cells. J. Biol. Chem. 266:6650-6656.

34. Uehara, Y., M. Hori, T. Takeuchi, and H. Umezawa. 1986. Phenotypic change from transformed to normal induced by benzoquinonoid ansamycins accompanies inactivation of $\mathbf{p 6 0}^{\mathrm{scc}}$ in rat kidney cells infected with Rous sarcoma virus. Mol. Cell. Biol. 6:2198-2206.

35. Levitzki, A., A. Gazit, N. Osherov, I. Posner, and C. Gilon. 1991. Inhibition of protein-tyrosine kinases by tyrphostins. Methods Enzymol. 201:347-361.

36. Akiyama, T., and H. Ogawara. 1991. Use and specificity of genistein as inhibitor of protein-tyrosine kinases. Methods Enzymol. 201:362-370.

37. Sukhatme, V. P. 1990. Early transcriptional events in cell growth: the egr family. J. Am. Soc. Nephrol. 1:859-866.

38. Cooper, D. R., J. E. Watson, M. Acevedo-Duncan, R. J. Pollet, M. L. Standaert, and R. V. Farese. 1989. Retention of specific protein kinase C isozymes following chronic phorbol ester treatment in $\mathrm{BC} 3 \mathrm{H}-1$ myocytes. Biochem. Biophys. Res. Commun. 161:327-334.

39. Huang, F. L., Y. Yoshida, J. R. Cunha-Melo, M. A. Beaven, and K.-P. Huang. 1989. Differential down-regulation of protein kinase $\mathrm{C}$ isozymes. J. Biol. Chem. 264:4238-4243.

40. Ase, K., N. Berry, U. Kikkawa, A. Kishimoto, and Y. Nishizuka. 1988. Differential down-regulation of protein kinase $\mathrm{C}$ subspecies in KM3 cells. FEBS (Fed. Eur. Biochem. Soc.) Lett. 236:396-400.

41. Cantley, L. C., K. R. Auger, C. Carpenter, B. Duckworth, A. Graziani, R. Kapeller, and S. Soltoff. 1991. Oncogenes and signal tranduction. Cell. 64:281302.

42. Campbell, G. S., L. J. Christian, and C. Carter-Su. 1993. Evidence for involvement of the growth hormone receptor-associated tyrosine kinase in actions of growth hormone. J. Biol. Chem. 268:7427-7434.

43. Yamaji, Y., O. W. Moe, R. T. Miller, and R. J. Alpern. 1993. Acidosis activates a Src-related tyrosine kinase in renal cells (abstr). J. Am. Soc. Nephrol. 4:506. (Abstr.)

44. Chao, M. V. 1992. Growth factor signaling: Where is the specificity? Cell. 68:995-997.

45. Miller, R. T., L. Counillon, G. Pages, R. P. Lifton, C. Sardet, and J. Pouyssegur. 1991. Structure of the 5'-flanking regulatory region and gene for the human growth factor-activatable $\mathrm{Na} / \mathrm{H}$ exchanger NHE-1. J. Biol. Chem. 266:10813-10819.

46. Reboucas, N. A., M. Blaurock, and P. Igarashi. 1991. Cloning of the 5' flanking sequence of a rabbit $\mathrm{Na} / \mathrm{H}$ exchanger gene (NAH-1). J. Am. Soc. Nephrol. 2:710. (Abstr.) 